\title{
Factors Affect Students Achievement in Their Examinations
}

\author{
Dr. Bakheit Mohammed Elnagar \\ Assistant Professor of Applied Linguistics \\ King Abdulaziz University, Jeddah, KSA
}

doi: 10.19044/esj.2016.v12n1p387 URL:http://dx.doi.org/10.19044/esj.2016.v12n1p387

\begin{abstract}
This study investigates the factors which affect the students' achievement in their examinations, mainly test anxiety. The effect of this anxiety was traced among Arab learners of English as a Foreign Language. The researcher used a questionnaire in order to get the necessary data about this psychological phenomenon. Data analysis was used to indicate that test anxiety is a natural psychological phenomenon that occurs due to lack of readiness or because of getting poor marks or grades. Moreover frantic reviews just before the test are more confusing methods than helpful ones. Students can reduce test anxiety through study habits and skills. Some recommendations were given to reduce these causes of anxiety.
\end{abstract}

Keywords: Factors, Test Anxiety, Achievement, King Abdulaziz University, EFL students

\section{Introduction}

Many factors affect students' achievement in their examinations. One of them is test anxiety which affects both the body and the mind. Students with test anxiety feel stressed out by their physical reaction and by thinking of too many things.

Test anxiety can create a vicious circle: the more a person focuses on the bad things that could happen, the stronger the feeling of anxiety becomes. This makes the person feels worse because his mind is preoccupied with distracting thoughts and fears. It can increase the possibility that the student will carry out improperly during the test.

Most students experience some level of anxiety before and during tests. However, when anxiety affects tests performance negatively, it becomes a problem. Several students participate in the class, do activities, homework, and come well prepared for the test, but when the day of the test comes, some of them freeze up, zone out, or feel so nervous that they can not 
pass the test. Hence, they can not respond properly to the questions, even if they know their answers. This is a clear case of test anxiety.

\section{Literature Review}

According to Gershaw (2001), students can not perform well in their examinations because of dominant feeling of anxiety. Test and performance anxiety occur in the presence of difficult threatening or challenging situations, when someone believes that he is inadequate or incapable of meeting the challenge and fears the consequences of possible failure.

It has been observed in the university level that almost every student suffers from this phenomenon.

Referring to Lash (2004: 2), students may experience the following symptoms when they psych out and their anxiety takes over.

1-distracting thoughts of failure.

2-an inability to pick out important environment cues.

3-becoming distracted by irrelevant environment cues.

4-interpreting the results of psychological arousal (muscle tension, heart rate, respiration) as signs of fear.

5-excessive muscle tension

6-attempting to avoid or escape the situation.

7-giving up.

Lash (2004: 2) has stated the following techniques for dealing with performance anxiety in twelve basic principles:

1-Be healthy: If someone is physically and emotionally exhausted, his body and mind will be less able to tolerate stress and anxiety. The student can improve his resistance to anxiety by getting adequate rest, eating appropriately, and taking care of his physical health.

2-Be prepared. Nothing can help reduce anxiety like confidence. If a student is over-prepared, his responses become more automatic, and his performance will be less affected by anxiety. Preparation for a test may include students' study and test-taking skills. The students must be on time and have all the tools that they need for a test such as pencils, calculator, pen and so on.

3-Practice the performance: The time limits of a test, the tied score of a game are stimuli that increase students' level of arousal and add to their experience of anxiety. If the students practice under similar conditions, they can become less sensitive to these stimuli.

4-Regulate students' arousal level: In cases of anxiety, the goal is to lower students' level of arousal. Some of the most effective ways involve changing students’ physical responses like breathing and muscle tension.

5-Deep breathing: When anxious students take shallow breaths, they may feel like they are not getting enough air, and get more anxious. If they 
focus on breathing deeply and slowly, their bodies and minds will begin to relax. To learn to breathe deeply, one can place his hand on the stomach and exhales in a way that makes his abdomen expands. As he exhales, the abdomen should move inward.

6-Progressive muscle relaxation: students tense their muscles when they are anxious. Practice muscle relaxation can be done by focusing on a particular muscle group (for example shoulders) and alternatively tensing and relaxing the muscle. Then focusing on releasing all of the tension in the muscle.

7-Reduce distractions: Distractions are additional stimuli that increase arousal. One can explore ways to reduce the distractions in his immediate environment, for example, sit in a back corner of the room, takes a sweater to prevent the distraction of being cold, changes seats if he is distracted by the person sitting next to him.

8-Rituals: Rituals are repetitive behaviours that give a sense of familiarity. They help to focus and reduce anxiety. Students may already have some rituals- getting a drink of water just before a test or using a particular pencil or pen. Students should make sure that their rituals are not harmful or distracting to themselves or others, for example, students tapping their pencils ten times before each question and this may annoy their classmates.

9-Control the fear: The underlying source of test or performance anxiety is the fear of failure. Students pay attention to what they are thinking and saying to themselves in anxious situations. This self-talk will likely reflect an expectation or fear of failure. The students can begin to control this fear or change the expectation by changing their self-talk.

10-Positive self-talk: One can determine the most important positive messages for himself by writing down his three or four most common negative thoughts for example, ("I can't do this"). Next, he can write down the opposite for each statement ("I can do this"). He can repeat the positives to himself daily for at least two weeks, and again just before and during the test.

11-On-task self-talk: Students can counter distractions and help themselves focus on the task at hand by telling themselves what to do. They talk themselves through the task step-by-step, and tell themselves that they are succeeding. In fact, thinking about past mistakes or future consequences is not helpful. They should focus on the present.

12-Gaining perspective: Sometimes the negative thoughts people have in stressful situations focus on potentially drastic consequences of failure. In most cases, these drastic consequences are much more severe than the reality of the situation and this is called catastrophizing. Thus, focusing 
on such catastrophic consequences increases anxiety and interferes with performance.

It is important to recognize that one mistake does not equal failure and that one bad performance does not mean you are worthless. (Lash, 2004).

Students must take some time to evaluate the most likely consequences of their performance. If they find that they tend to catastrophize, they can develop some phrases that are more realistic and repeat these phrases to themselves prior to and during the test.

People who worry a lot or who are perfectionists are more likely to have trouble with test anxiety. People with these traits sometimes find it hard to accept mistakes they might make or to get anything less than a perfect score. In this way, even without meaning to, they might really pressure themselves. Test anxiety is bound to thrive in a situation like this.

Students who are not prepared for tests, but who care about doing well are also likely to experience test anxiety. If the students are not prepared, they actually will be worried about doing poorly.

(Lyness, 2004: 3) explains that

People can feel unprepared for tests for several reasons: They may not have studied enough, they may find the material difficult, or perhaps they feel tired because they did not get enough sleep the night before.

Test anxiety can be a real problem when someone is so stressed out over a test that he can not get past the nervousness to focus on the test questions and do his best work. In fact, feeling ready to meet the challenge, though, can keep test anxiety at manageable level.

Some students think that going to class is all it should take to learn and do well on tests. But there is much more to learning than just hoping to soak everything up in class. That is why good study habits and skills are so important and no amount of cramming or studying the night before a test can take the place of the deeper level of learning that happens over time with regular study.

Many students find that their test anxiety is reduced when they start to study better or more regularly. It makes sense that the more one knows the material, the more confident he will feel. Having confidence going into a test means a student expects to do well. If a student is thinking negative thoughts such as "I'm never any good at taking tests," or "It's going to be terrible if I do badly on this test", the student can replace them with positive messages, such as "I have studied hard and I know the material, so I'm ready to do the best I can". Another thing that he can do is to learn to keep mistakes in perspective-especially if he is a perfectionist. Some students tend to be hard on themselves. Everyone makes mistakes and they could accept mistakes. The students should take care of their health such as getting enough sleep, 
exercise and healthy food before a test. These can help keep their minds working at their best.

Everything takes time and practice, and learning to beat test anxiety is no different. Although it won't go away overnight, facing and dealing with test anxiety will help students learn stress management, which can prove to be a valuable skill in many situations besides taking tests.

Nolting (2000: 3) mentions that there are two different types of test anxiety:

1-One type of test anxiety is somatic, which is what people are feeling.

2-The second type of test anxiety is cognitive, which is what people are thinking. follows:

Nolting (2000: 3) has summarized the main causes of test anxiety as

1-Test anxiety is a learned behaviour.

2-The association of grades and personal worth causes test anxiety.

3- Test anxiety can come from a feeling of a lack of control.

4- Test anxiety can be caused by a teacher embarrassing a student.

5-Being placed into a course above one's ability can cause test anxiety.

6-Test anxiety develops from fear of alienation from parents, family and friends due to poor grades.

7-Test anxiety can be caused by timed tests and the fear of not finishing the test, even if one can do all the problems.

It is more common among students who anticipate predestinated formal test, he will impose to do a lot of mental, physical and emotional calculations. As a student enters the classroom he is aware that he is nervous, his heart is beating faster and that his muscles are tense. By the time the test is handed out hands are cold and clammy. He begins to feel that he has lost the ability to remember what studied the night before. His mind refuses to work and he feels frustrated and upset. After the test, everything that he could not remember suddenly comes back to him. He becomes angry with himself because he could not think properly during the test.

The physical aspects of test anxiety are biological, consisting of hormonal, chemical, and muscular changes in the body. The by-product of this condition is interference with the thinking process. The physical symptoms can include muscle tension, nausea, shortness of breath, clammy hands, rapid heartbeat, and feeling faint. When these symptoms are present, basic thinking processes like remembering, analyzing, and problem solving are affected. This is the reason for students who experience test anxiety feel that their brain is just not working right. 
The biological state of fear or anxiety occurs in response to a perceived threat. The purpose of this biological reaction is to keep the body vigilant, ready to run or flight if necessary. This is the so-called "fight or flight" response that was necessary for humans thousands of years ago (ibid). This primitive biological response can cause problems in today's society. A person's natural reaction is to run away from, or avoid a perceived threat. This is not possible in a classroom, and being required to remain in the presence of a perceived threat, that is, the test which can only increase the symptoms. The physical symptoms and anxiety become a vicious cycle from which the person can not escape. If the anxiety becomes too great, a person's brain will in effect shut down. This is the body's way of dealing with an intolerably high level of stress that cannot be removed.

Anxiety can be created by a person's expectations concerning what is likely to happen. These expectations may be expressed in words to oneself, mental pictures, or physical symptoms. If a student believes, for example, that he is going to perform poorly, has not studied enough, or will appear foolish, he will have an emotional reaction consistent with that expectation. The mental state of the student produces a corresponding emotional reaction..

Avoidance is a typical behaviour pattern of students who experience test anxiety. Students who experience test anxiety may have a problem with procrastination. They often avoid studying, and then a day or two before the test they start to worry that they have not studied enough. Procrastination also leads to last-minute cramming, which can result in the information becoming disorganized in the student's brain. This pattern of avoidance leads to a vicious cycle. Procrastination leads to last minute cramming, which leads to anxiety, to self-doubts, to excessive anxiety during a testing situation, which may lead to the inability to remember or think logically.

In addition to feeling unprepared, test anxiety may result from concern about how others will view it if they do poorly. Students who experience test anxiety tend to be the type of people who put a lot of pressure on themselves to perform well. They often have unusually high expectations for themselves and, many times, have been very good students in the past. When these students begin to experience low grades for the first time, they put pressure on themselves to perform better, but oftentimes put off studying longer than they should. This may begin a cycle of self-doubts and irrational beliefs that can result in high anxiety level during testing situations.

In conclusion, test anxiety is the result of many interrelated beliefs, habits and experience. Ineffective study methods, and procrastination can lead to anxiety and a lowered self-image. Poor performance in a course can lead to increased pressure on oneself, especially if the outcome of a test of a course is very important. A single experience of extreme test anxiety can 
leave a student uncertain if it will occur again. The good news for students who experience test anxiety is that it may be easily overcome if one is willing to follow some guidelines and practice some well-established techniques.

Instructors can play an important role in reducing their students' test anxiety. (Budd, 2002: 3) offers helpful tips to relieve exam anxiety including:

1.No textbooks: Students have to make sure that they do not only understand the information when they do the work, but also they remember the material from the first time they study it well enough to pass a test.

2.Stress: Taking tests adds stress. Students' performance tends to deteriorate under stress. Thus, they need to learn the material well enough to remember it under stress.

3.Time pressure: Students have studied several chapters and lessons, learned hundreds of facts, concepts, processes, solutions in many days. They will need to remember this rapidly in one forty-five minute test setting.

When studying with a textbook, they check each chapter outline. They will be valuable in at least two ways: as a check to see how well they remember the chapter after studying it the first time, and as a way of remembering the material. They remember more details longer if they are organized. The chapter outline will usually provide an organization for text and lesson materials. Students certainly test themselves after studying so that they will remember the material on the test day and in fact the textbook will not be in front of them when they are taking the test. Short and regular study periods are more productive than lengthy single sessions.

Turner (2003: 8) demonstrates many examples and reasons of why staying calm is essential throughout secondary school career. To do well, all one needs to do is to follow them in the following quotation.

There are many categories that deal with staying calm during tests. The first category is preparation. Before students take a test, they organize in advance. They don't wait until the last minute to do their studying. The students make sure that they get a good night's rest the day before the test, and they stop studying before they are about to take the test in order to relax. It's important to know the time and place of the test, and what they need to bring. They take the test on time, but they don't be too late or too early.

Beforehand, they don't talk about what's on the test with peers because it may raise the level of concern. Before they start to answer, they read the test over so they can plan their approach out in the best fit way. If they receive any difficulty on a question, they do not be afraid to get 
clarification from a teacher. They can develop an aggressive attitude towards learning and understanding the concept that will help them do their best on the test using all of their knowledge to their advantage.

Poop (2000: 1) takes into consideration six very logical, but yet useful tips on doing well on tests. The first tip is to try to get the highest possible score on the test being taken. This means, the students should put every effort they have into their work so that they can earn every possible point, which will eventually result in a higher grade.

The second suggestion that Poop (2000) is delineated in the following statement:

....although students would do better if they had more time on a test, they won't always get it, therefore; it is essential that test time must be used very efficiently and effectively. Some ways to conserve time before even taking the test are as follows: students take more paper, extra pens, pencils, rulers, and calculators to the test, as well as arrive awake and on time. Even marking important points in notes they have taken and book they are allowed to use on the test will save time so that they don't have to frantically flip through pages. When taking the test, it is best to skip over problems that cause them too much trouble and waste time. It is best to go back to these problems if time permits. After the test, students should write down everything they believe they did to waste time on the test. These mistakes should be taken into consideration for the next test.

Then, instructors and learners should mind the value of time and should not waste it by dividing the time according to the questions and range of difficulty and length. Moreover, students should leave what is difficult and start with from the easy questions to the difficult ones.

Suggestion number three says students never go back and change an answer they have already written down unless they are totally positive that it was wrong in the first place.

As logical as it sounds, number four says that students should never cram for a test. Cramming not only adds to test anxiety, but also doesn't actually help students learn anything. The information crammed the night before a test will not stick very long, and when it comes to the final exam, they won't remember a thing. It is recommended that students should review the class lesson everyday so that when it comes to study, the information won't seem so new and therefore will be not as hard to master.

Number five states to work the whole test. Answering all parts of a question is very important when taking a test. Many points are taken off when students don't fully answer a question asked. It is even said that 
highlighting important parts of questions will prevent a student from forgetting an important part of one.

The last suggestion says not to do the first problem of a test first. When students see the first question of a test and automatically think it is impossible, they are likely to come to the conclusion that they are bound to fail the test, and will therefore do worse since they don't have any confidence in themselves. By starting with the second problem or even the last problem, students should not have to deal with "first-question anxiety syndrome" as "I'd like to call it". Although this might not work in all cases, such as if they have no clue about any of the information on the test, it does work if they know their teacher is the type that puts the hardest question as the first question on the test.

In order to perform well on test and not to get stressed or nervous, students must have the right mind set. If a student thinks to himself "I know I'm going to fail, I know this will be impossible", he will be bound to do badly. If he feels confident, his chances are greater that he will do better.

Before a test begins, Cole (2003: 3) suggests that students get enough sleep, they eat healthy, and exercise. These in turn will help them take a test. Also, being well rested is one of the most important yet overlooked aspects of having a focused mind. They can evaluate the things going on in their life for any stress indicators that may interfere with test preparation, such as a fight between friends, feeling overwhelmed, or overly pressures. Recognizing these anxiety points and removing them by turning on a positive attitude assist in being able to better preparations for tests.

In order students to do well on their tests, their stress and anxiety must be reduced to a minimum. Petrowski (2002: 1) gives tips to explain what a student should do before, and during the test. Some of these tips include:

1.Be thoroughly prepared. A confident knowledge of course material is the first step in reducing test anxiety.

2.Review material. Review should be spaced throughout the week. This aids memory development and retention. And some initial tension is normal. Generally, when students receive the test, they stop for a moment, take a few deep breaths and exhale slowly, relax, and then they start reviewing directions and test items. In a timed test, make a schedule for answering questions. They allow more time for higher point questions and pace themselves to answer as many questions as possible.

Furthermore, physical preparation is also a decided factor in remaining students calm throughout their tests. Some of the physical preparation tips include:

1.Before the test, develop good study habits and techniques. Adequate food and rest are an important part of any study programme, 
especially before a test. When people are tired, they become frustrated easier and experience more anxiety.

2.During the test, find a place where you will have some privacy, that is well-lighted and comfortable. Bring everything they will need (scratch paper, pencils, calculator, and so on). Avoid locating themselves near doors or other high distraction areas.

\section{Methodology}

The adopted methodology to accomplish this study uses the following techniques: the information about the research design, research population, questionnaire design, statistical data analysis, content validity and pilot study.

The first phase of the research thesis proposal included identifying and defining the problems and establishment objective of the study and development research plan.

The second phase of the research included a summary of the comprehensive literature review. Literatures on claim management was reviewed.

The third phase of the research included a field survey which was conducted with " Factors Affect Students Achievement in Their Examination"

The fourth phase of the research focused on the modification of the questionnaire design, through distributing the questionnaire to pilot study, The purpose of the pilot study was to test and prove that the questionnaire questions are clear to be answered in a way that help to achieve the target of the study. The questionnaire was modified based on the results of the pilot study.

The fifth phase of the research focused on distributing questionnaire. This questionnaire was used to collect the required data in order to achieve the research objective.

The sixth phase of the research was data analysis and discussion. Statistical Package for the Social Sciences, (SPSS) was used to perform the required analysis. The final phase includes the conclusions and recommendations. 
Figure (1) shows the methodology flowchart, which leads to achieve the research objective.

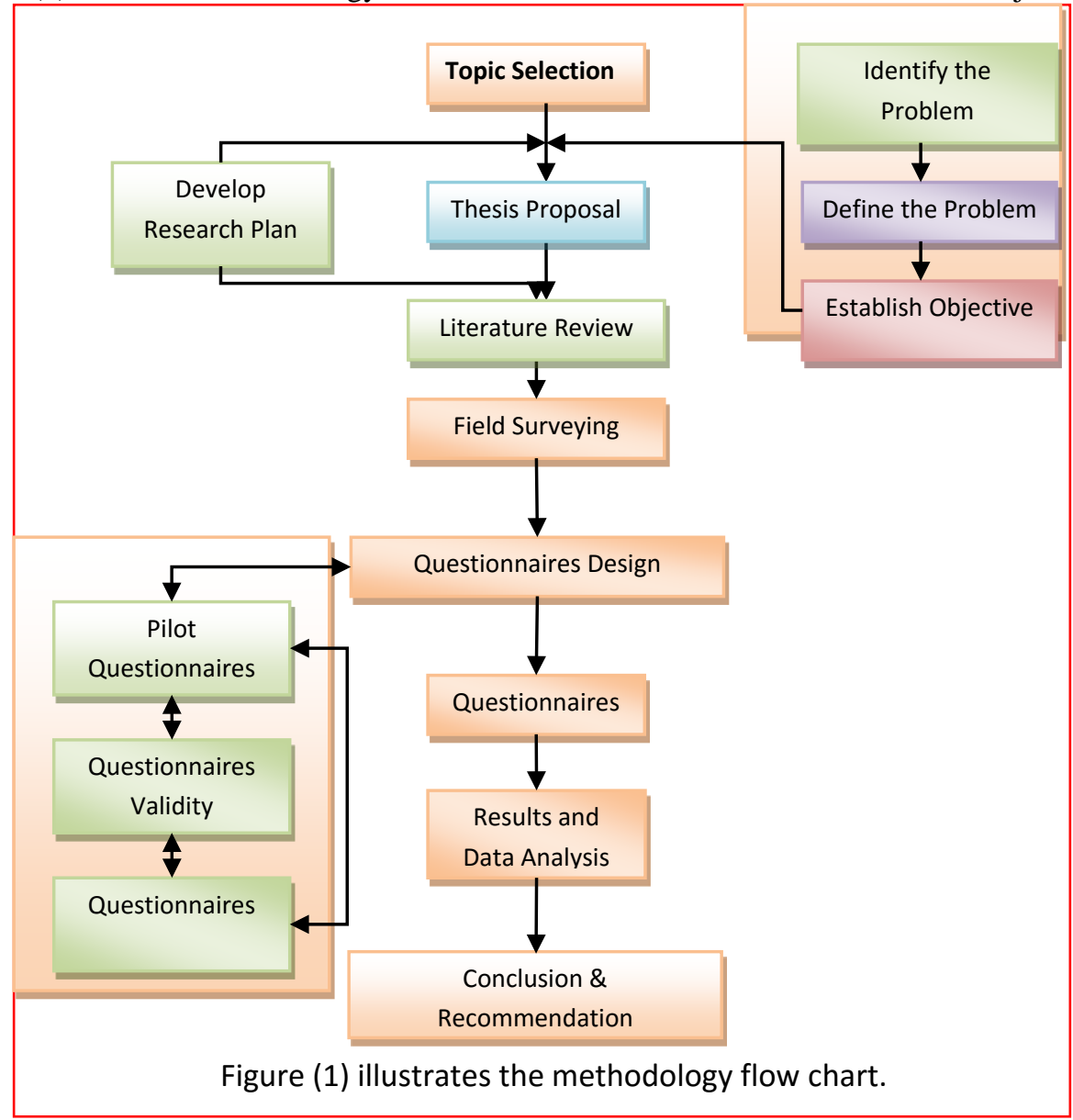

In order to collect the needed data for this research, we use the secondary resources in collecting data such as books, journals, statistics and web pages, in addition to preliminary resources that not available in secondary resources through distribute questionnaires on study population in order to get their opinions about " Factors Affect Students Achievement in Their Examination ".

Research methodology depends on the analysis of data on the use of descriptive analysis, which depends on the poll and use the main program (SPSS).

\section{Population and Sampling}

The population includes EFL students at King Abdulaziz University. The sample of this study consists of (100) male and female students. Questionnaires were distributed to the research population all questionnaires 
are received, and the following tables illustrated the properties of the samples:

\section{Reliability of the Research}

Reliability of an instrument is the degree of consistency with which it measures the attribute it is supposed to be measuring . The test is repeated to the same sample of people on two occasions and then compares the scores obtained by computing a reliability coefficient. For the most purposes reliability coefficient above 0.70 are considered satisfactory. Period of two weeks to a month is recommended between two tests Due to complicated conditions that the consumer is facing at the time being, it was too difficult to ask them to responds to our questionnaire twice within short period. The statistician's explained that, overcoming the distribution of the questionnaire twice to measure the reliability can be achieved by using Kronpakh Alpha coefficient through the SPSS software.

\section{Cronbach's Coefficient Alpha}

This method is used to measure the reliability of the questionnaire between each field and the mean of the whole fields of the questionnaire. The normal range of Cronbach's coefficient alpha value between ( 0.0 and + 1.0), and the higher values reflects a higher degree of internal consistency. As shown in table below the Cronbach's coefficient alpha was calculated. The general reliability for all items in each sections ranges from( 0.851 to 0.872). This range is considered high; the result ensures the reliability of the questionnaire, these ranges are less than Cornbach's coefficient alpha (0.873) this indicate there is a high consistency.

\begin{tabular}{|c|c|c||}
\hline No. & question & $\begin{array}{c}\text { Cronbach's Alpha if Item } \\
\text { Deleted }\end{array}$ \\
\hline 1 & I feel worried when test schedules are announced. & .870 \\
\hline 2 & I prepare a programme to memorize the subject of the test. & .862 \\
\hline 3 & I take hot drinks before the test. & .871 \\
\hline 4 & I take enough rest before the test. & .871 \\
\hline 5 & I find difficulty in going to sleep the night before the test. & .862 \\
\hline 6 & I feel afraid before the test in spite of my good preparation. & .852 \\
\hline 7 & I always expect failure despite my careful preparation. & .872 \\
\hline 8 & I arrive at the test place early. & .851 \\
\hline 9 & I always feel that test instructions are not clear. & .857 \\
\hline 10 & In the test, I answer the difficult questions first and then & .853 \\
\hline 11 & the easy ones. & .864 \\
\hline 12 & I spend much time in answering each question. & .859 \\
\hline 13 & It is always difficult for me to answer objective questions, & .870 \\
\hline 14 & such as MCQs* and true/false questions. & .860 \\
\hline 15 & I encounter problems in answering oral tests questions. & Cronbach's Alpha = 0.873 \\
\hline & No get poor grades, even if I try to answer well. & \\
\hline
\end{tabular}




\section{Validity of the Research}

We can define the validity of an instrument as a determination of the extent to which the instrument actually reflects the abstract construct being examined. "Validity refers to the degree to which an instrument measures what it is supposed to be measuring". High validity is the absence of systematic errors in the measuring instrument. When an instrument is valid; it truly reflects the concept it is supposed to measure. Achieving good validity required the care in the research design and sample selection. The amended questionnaire was by the supervisor and three expertise in the tendering and bidding environments to evaluate the procedure of questions and the method of analyzing the results. The expertise agreed that the questionnaire was valid and suitable enough to measure the purpose that the questionnaire designed for.

\section{Content Validity of the Questionnaire}

Content validity test was conducted by consulting two groups of experts. The first was requested to evaluate and identify whether the questions agreed with the scope of the items and the extent to which these items reflect the concept of the research problem. The other was requested to evaluate that the instrument used is valid statistically and that the questionnaire was designed well enough to provide relations and tests between variables. The two groups of experts did agree that the questionnaire was valid and suitable enough to measure the concept of interest with some amendments.

\section{Statistical Validity of the Questionnaire}

To insure the validity of the questionnaire, two statistical tests should be applied. The first test is Criterion-related validity test (Pearson test) which measure the correlation coefficient between each item in the field and the whole field. The second test is structure validity test (Pearson test) that used to test the validity of the questionnaire structure by testing the validity of each field and the validity of the whole questionnaire. It measures the correlation coefficient between one filed and all the fields of the questionnaire that have the same level of similar scale.

\section{Criterion Related Validity Internal consistency:}

Internal consistency of the questionnaire is measured by a scouting sample, which consisted of twenty five questionnaires, through measuring the correlation coefficients between each question in one field and the whole filed. The table below shows the correlation coefficient and p-value for each field items. As show in this table the p- Values are less than (0.05) 
or(0.01), so the correlation coefficients of this field are significant at $\alpha=$ (0.01) or $\alpha=(0.05)$, so it can be said that the paragraphs of this field are consistent and valid to be measure what it was set for.

\begin{tabular}{|c|c|c|c|}
\hline No. & question & $\begin{array}{c}\text { Pearson } \\
\text { coefficient }\end{array}$ & p-value \\
\hline 1 & I feel worried when test schedules are announced. & $.415^{* *}$ & 0.000 \\
\hline 2 & $\begin{array}{c}\text { I prepare a programme to memorize the subject of the } \\
\text { test. }\end{array}$ & $.568^{* *}$ & 0.000 \\
\hline 3 & I take hot drinks before the test. & $.534^{* *}$ & 0.000 \\
\hline 4 & I take enough rest before the test. & $.334^{* *}$ & 0.000 \\
\hline 5 & $\begin{array}{c}\text { I find difficulty in going to sleep the night before the } \\
\text { test. }\end{array}$ & $.586^{* *}$ & 0.000 \\
\hline 6 & I feel afraid before the test in spite of my good \\
preparation. & $.550^{* *}$ & 0.000 \\
\hline 7 & I always expect failure despite my careful \\
\hline 8 & I arrive at the test place early. & $.750^{* *}$ & 0.000 \\
\hline 9 & I always feel that test instructions are not clear. \\
\hline 10 & $\begin{array}{c}\text { In the test, I answer the difficult questions first and } \\
\text { then the easy ones. }\end{array}$ & $.464^{* *}$ & 0.000 \\
\hline 11 & I spend much time in answering each question. & $.698^{* *}$ & 0.030 \\
\hline 12 & I find difficulty in answering subjective questions. & $.714^{* *}$ & 0.024 \\
\hline 13 & $\begin{array}{c}\text { It is always difficult for me to answer objective } \\
\text { questions, such as MCQs* and true/false questions. }\end{array}$ & $.765^{* *}$ & 0.005 \\
\hline 14 & I encounter problems in answering oral tests \\
questions. & $.367^{* *}$ & 0.000 \\
\hline 15 & $\begin{array}{r}\text { I expect to get poor grades, even if I try to answer } \\
\text { well. }\end{array}$ & $.676^{* *}$ & 0.000 \\
\hline
\end{tabular}

\section{Statistical Manipulation:}

To achieve the research goal, researcher used the statistical package for the Social Science (SPSS) for Manipulating and analyzing the data.

\section{Statistical methods are as follows:}

\section{1- Frequencies and Percentile}

2- Alpha- Cronbach Test for measuring reliability of the items of the questionnaires

3- Person correlation coefficients for measuring validity of the items of the questionnaires.

5- One sample t test

6. independent sample t test to test the difference between to means of samples.

7- One way ANOVA test for the difference between means three samples or more

8- Scheffe test for Multiple Comparisons 
Personal information:

\begin{tabular}{|c|c|c|}
\hline Gender & Frequency & Percentages \\
\hline Male & 48 & 48.0 \\
\hline Female & 52 & 52.0 \\
\hline Total & 100 & 100.0 \\
\hline
\end{tabular}

\section{Percentages}

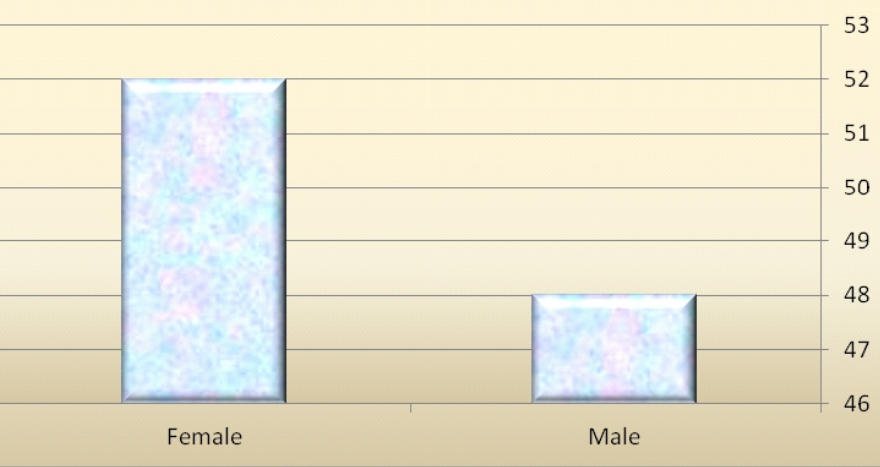

\section{Level:}

\begin{tabular}{|c|c|c|}
\hline Level & Frequency & Percentages \\
\hline $1^{\text {st }}$ & 22 & 22.0 \\
\hline $2^{\text {nd }}$ & 23 & 23.0 \\
\hline $3^{\text {rd }}$ & 31 & 31.0 \\
\hline $6^{\text {th }}$ & 24 & 24.0 \\
\hline Total & 100 & 100.0 \\
\hline
\end{tabular}

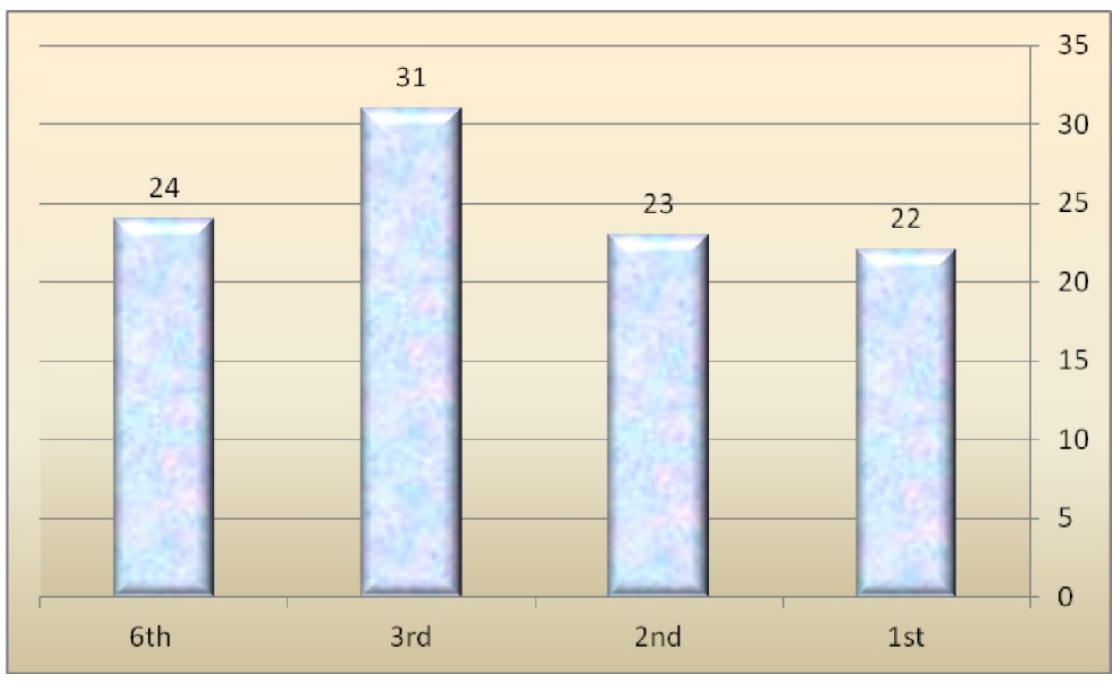




\section{Discussion and Hypotheses Test \\ Tests of Normality}

One-sample K-S test will be used to identify if the data follows normal distribution or not, this test is considered necessary in case of testing hypotheses as most parametric Test stipulate data to be normality distributed and this test used when the size of the sample are greater or equal than or equal 100.

Results test as shown in the table below which clarifies that the calculated p-value is greater than the significant level which is equal (0.05) ( p-value $>0.05$ ), this in turn denotes that data follows normal distribution, and so parametric Tests must be used.

One-sample K-S

\begin{tabular}{|c|c|c|}
\hline Statistic test & df & P-value \\
\hline 1.170 & 99 & .129 \\
\hline
\end{tabular}

In the following table, one sample t test is used to test if the opinion of the respondent in the content of the items are positive ( weight mean greater than "60.0\%" and the p-value less than 0.05 ) or the opinion of the respondent in the content of the items are neutral ( p- value is greater than 0.05 ) or the opinion of the respondent in the content of the items are negative (weight mean less than "60.0\%" and the p-value less than 0.05) .

1. In item No. (1) the weight mean equal " 4.28\%" and p-value equal " 0.000 " which is less than 0.05 , that (they feel worried when test schedules are announced).

2. In item No (8) the weighted mean equal "4.12" and p-value "0.000", which less than 0.05 , that (they arrive at the test place early).

3. In item No (6) the weighted mean equal "4.05" and p-value equal "0.000" which is less than 0.05 , that ( they feel afraid before the test in spite of my good preparation).

4. In item No (4) the weighted mean equal "3.94" and p-value "0.000" which is less than 0.05 , that (I take enough rest before the test).

5. In item No (14) the weighted mean equal "3.88" and p-value equal "0.000" which is less than 0.05 , that (They encounter problems in answering oral tests questions).

6. In item No (2) the weighted mean equal "3.67" and p-value "0.000" which less than 0.05 , that (they prepare a programme to memorize the subject of the test.).

7. In item No (12) the weighted mean equal "3.67" and p-value '.000' which less than 0.05 , that (they find difficulty in answering subjective questions). 
8. In item No (5) the weighted mean equal "3.58" and p-value "0.000" which less than0.05,that (they find difficulty in going to sleep the night before the test).

9. In item No (3) the weighted mean equal "3.55" and p-value "0.000" which less than 0.05 , that ( they take hot drinks before the test).

10. In item No (7) the weighted mean equal "3.55" and p-value "0.000" which less than 0.05, that (they always expect failure despite my careful preparation).

11. In item No (15) the weighted mean equal "3.39" and p-value "0.002" which less than0.05, that they (expect to get poor grades, even if I try to answer well).

12. In item No (10) the weighted mean equal "3.34" and p-value "0.012" which less than0.05, that (In the test, I answer the difficult questions first and then the easy ones.).

13. In item No (11) the weighted mean equal "3.23" and p-value "0.064" which greater than 0.05 , that ( they not spend much time in answering each question).

14. In item No (9) the weighted mean equal "3.09" and p-value "0.431" which greater than 0.05, that ( they always not feel that test instructions are not clear).

15. In item No (13) the weighted mean equal "3.11" and p-value "0.494" which greater than 0.05, that (It is always not difficult for me to answer objective questions, such as MCQs* and true/false questions).

\section{Questionnaire Respondents}

\begin{tabular}{|c|c|c|c|c|c|c|}
\hline No. & Items & Mean & $\begin{array}{l}\text { standard } \\
\text { deviation }\end{array}$ & $\begin{array}{c}\mathrm{t}- \\
\text { value }\end{array}$ & $\begin{array}{c}\text { P- } \\
\text { value }\end{array}$ & Rank \\
\hline 1 & $\begin{array}{l}\text { I feel worried when test schedules are } \\
\text { announced. }\end{array}$ & 4.28 & 0.91 & 14.051 & .000 & 1 \\
\hline 8 & I arrive at the test place early. & 4.12 & 0.70 & 15.992 & .000 & 2 \\
\hline 6 & $\begin{array}{l}\text { I feel afraid before the test in spite of my } \\
\text { good preparation. }\end{array}$ & 4.05 & 0.99 & 10.621 & .000 & 3 \\
\hline 4 & I take enough rest before the test. & 3.94 & 1.09 & 8.623 & .000 & 4 \\
\hline 14 & $\begin{array}{c}\text { I encounter problems in answering oral tests } \\
\text { questions. }\end{array}$ & 3.88 & 1.03 & 8.563 & .000 & 5 \\
\hline 2 & $\begin{array}{l}\text { I prepare a programme to memorize the } \\
\text { subject of the test. }\end{array}$ & 3.67 & 1.02 & 5.081 & .000 & 6 \\
\hline 12 & $\begin{array}{l}\text { I find difficulty in answering subjective } \\
\text { questions. }\end{array}$ & 3.67 & 1.14 & 5.890 & .000 & 7 \\
\hline 5 & $\begin{array}{l}\text { I find difficulty in going to sleep the night } \\
\text { before the test. }\end{array}$ & 3.58 & 1.31 & 4.421 & .000 & 8 \\
\hline 3 & I take hot drinks before the test. & 3.55 & 1.16 & 4.026 & .000 & 9 \\
\hline 7 & $\begin{array}{l}\text { I always expect failure despite my careful } \\
\text { preparation. }\end{array}$ & 3.55 & 1.36 & 4.750 & .000 & 10 \\
\hline 15 & $\begin{array}{l}\text { I expect to get poor grades, even if I try to } \\
\text { answer well. }\end{array}$ & 3.39 & 1.21 & 3.236 & .002 & 11 \\
\hline
\end{tabular}




\begin{tabular}{|c|c|c|c|c|c|c|}
\hline No. & Items & Mean & $\begin{array}{c}\text { standard } \\
\text { deviation }\end{array}$ & $\begin{array}{c}\mathrm{t}- \\
\text { value }\end{array}$ & $\begin{array}{c}\text { P- } \\
\text { value }\end{array}$ & Rank \\
\hline 10 & $\begin{array}{c}\text { In the test, I answer the difficult questions } \\
\text { first and then the easy ones. }\end{array}$ & 3.34 & 1.33 & 2.547 & .012 & 12 \\
\hline 11 & $\begin{array}{c}\text { I spend much time in answering each } \\
\text { question. }\end{array}$ & 3.23 & 1.23 & 1.870 & .064 & 13 \\
\hline 9 & $\begin{array}{c}\text { I always feel that test instructions are not } \\
\text { clear. }\end{array}$ & 3.11 & 1.39 & .790 & .431 & 14 \\
\hline 13 & $\begin{array}{c}\text { It is always difficult for me to answer } \\
\text { objective questions, such as MCQs* and } \\
\text { true/false questions. }\end{array}$ & 3.09 & 1.31 & .686 & .494 & 15 \\
\hline & All items & 3.63 & 1.17 & 50.35 & 0.000 & \\
\hline
\end{tabular}

Critical value of t at df "99" and significance level 0.05 equal 1.99

To test the hypothesis the Independent sample $\mathrm{T}$ test is used to test the correspondences of the sample about questions due to gender ( Male , Female) and the result illustrated in the table below which shows that the pvalue for each item is less than (0.05) and the absolute value of $\mathrm{T}$ test for each item is less than the critical value which is equal (1.99) that means there is statistically significant differences at the level of $\alpha=(0.05)$ in each items, except questions $(1,4,6,8,14)$.

For general that the p-value for all items equal (0.000) which is less than (0.05) and the absolute value of $T$ test for all items equal (9.770) which is greater than the critical value which is equal 1.99 , that's mean there is difference in the study questions based on gender ( Male, Female) at significance level $\alpha=(0.05)$.

\begin{tabular}{|c|c|c|c|c|c|}
\hline Items & Gender & Mean & $\begin{array}{c}\text { Std. } \\
\text { Deviation }\end{array}$ & $\mathrm{T}$ test & $\mathrm{p}$ - value \\
\hline \multirow{2}{*}{$\begin{array}{l}\text { I feel worried when test schedules are } \\
\text { announced. }\end{array}$} & Male & 4.42 & 0.71 & \multirow{2}{*}{1.472} & \multirow{2}{*}{.145} \\
\hline & Female & 4.15 & 1.06 & & \\
\hline \multirow{2}{*}{ I arrive at the test place early. } & Male & 4.40 & 0.68 & \multirow{2}{*}{6.372} & \multirow{2}{*}{.000} \\
\hline & Female & 3.00 & 1.41 & & \\
\hline \multirow{2}{*}{$\begin{array}{l}\text { I feel afraid before the test in spite of my } \\
\text { good preparation }\end{array}$} & Male & 4.17 & 0.91 & \multirow{2}{*}{4.883} & \multirow{2}{*}{.000} \\
\hline & Female & 2.98 & 1.48 & & \\
\hline \multirow{2}{*}{ I take enough rest before the test. } & Male & 4.02 & 0.96 & \multirow{2}{*}{.717} & \multirow{2}{*}{.475} \\
\hline & Female & 3.87 & 1.21 & & \\
\hline \multirow{2}{*}{$\begin{array}{l}\text { I encounter problems in answering oral } \\
\text { tests questions. }\end{array}$} & Male & 3.98 & 1.04 & \multirow{2}{*}{3.081} & \multirow{2}{*}{.003} \\
\hline & Female & 3.21 & 1.43 & & \\
\hline \multirow{2}{*}{$\begin{array}{l}\text { I prepare a programme to memorize the } \\
\text { subject of the test. }\end{array}$} & Male & 4.23 & 0.78 & \multirow{2}{*}{1.785} & \multirow{2}{*}{.078} \\
\hline & Female & 3.88 & 1.13 & & \\
\hline \multirow{2}{*}{$\begin{array}{l}\text { I find difficulty in answering subjective } \\
\text { questions. }\end{array}$} & Male & 4.25 & 0.60 & \multirow{2}{*}{7.287} & \multirow{2}{*}{.000} \\
\hline & Female & 2.90 & 1.18 & & \\
\hline \multirow{2}{*}{$\begin{array}{l}\text { I find difficulty in going to sleep the } \\
\text { night before the test. }\end{array}$} & Male & 4.21 & 0.68 & \multirow{2}{*}{1.217} & \multirow{2}{*}{.227} \\
\hline & Female & 4.04 & 0.71 & & \\
\hline \multirow{2}{*}{ I take hot drinks before the test. } & Male & 4.21 & 0.65 & \multirow{2}{*}{11.873} & \multirow{2}{*}{.000} \\
\hline & Female & 2.10 & 1.09 & & \\
\hline \multirow{2}{*}{$\begin{array}{l}\text { I always expect failure despite my } \\
\text { careful preparation. }\end{array}$} & Male & 4.15 & 0.82 & \multirow{2}{*}{7.222} & \multirow{2}{*}{.000} \\
\hline & Female & 2.60 & 1.29 & & \\
\hline I expect to get poor grades, even if I try & Male & 3.92 & 0.85 & 6.423 & .000 \\
\hline
\end{tabular}




\begin{tabular}{|c|c|c|c|c|c|}
\hline Items & Gender & Mean & $\begin{array}{c}\text { Std. } \\
\text { Deviation }\end{array}$ & $\mathrm{T}$ test & p-value \\
\hline to answer well. & Female & 2.60 & 1.19 & & \\
\hline \multirow{2}{*}{$\begin{array}{l}\text { In the test, I answer the difficult } \\
\text { questions first and then the easy ones }\end{array}$} & Male & 3.96 & 0.68 & \multirow{2}{*}{2.561} & \multirow{2}{*}{.012} \\
\hline & Female & 3.40 & 1.39 & & \\
\hline \multirow{2}{*}{$\begin{array}{l}\text { I spend much time in answering each } \\
\text { question. }\end{array}$} & Male & 4.00 & 0.68 & \multirow{2}{*}{9.122} & \multirow{2}{*}{.000} \\
\hline & Female & 2.25 & 1.19 & & \\
\hline \multirow{2}{*}{$\begin{array}{l}\text { I always feel that test instructions are not } \\
\text { clear. }\end{array}$} & Male & 3.92 & 0.71 & \multirow{2}{*}{.348} & \multirow{2}{*}{.728} \\
\hline & Female & 3.85 & 1.26 & & \\
\hline \multirow{2}{*}{$\begin{array}{l}\text { It is always difficult for me to answer } \\
\text { objective questions, such as MCQs* and } \\
\text { true/false questions. }\end{array}$} & Male & 4.10 & 0.66 & \multirow[b]{2}{*}{7.062} & \multirow[b]{2}{*}{.000} \\
\hline & Female & 2.73 & 1.22 & & \\
\hline \multirow{2}{*}{ All items } & Male & 61.92 & 8.07 & \multirow{2}{*}{9.770} & \multirow{2}{*}{.000} \\
\hline & Female & 47.56 & 6.46 & & \\
\hline
\end{tabular}

Critical value of t at df "99" and significance level 0.05 equal 1.99

The above table shows that the p-value for each item is less than (0.05) and the absolute value of $F$ test for each item is less than the critical value which is equal (2.68) that means there is statistically significant differences at the level of $\alpha=(0.05)$ in each items., except questions $(1,6,8,12)$.

For general that the p-value for all items equal (0.000) which is less than (0.05) and the absolute value of F test for all items equal (30.466) which is greater than the critical value which is equal (2.68), that's mean there is difference in the study questions based on level (first, second , third , sixth) at significance level $\alpha=(0.05)$.

\begin{tabular}{|c|c|c|c|c|c|}
\hline Items & Level & Mean & $\begin{array}{c}\text { Std. } \\
\text { Deviation }\end{array}$ & F test & $\begin{array}{c}\text { p- } \\
\text { value }\end{array}$ \\
\hline \multirow{4}{*}{$\begin{array}{l}\text { I feel worried when test schedules } \\
\text { are announced. }\end{array}$} & $1 \mathrm{st}$ & 4.7273 & .45584 & \multirow{4}{*}{2.533} & \multirow{4}{*}{.061} \\
\hline & 2nd & 4.2609 & .86431 & & \\
\hline & 3rd & 4.0968 & 1.16490 & & \\
\hline & 6th & 4.1250 & .79741 & & \\
\hline \multirow{4}{*}{ I arrive at the test place early. } & $1 \mathrm{st}$ & 4.6818 & .56790 & \multirow{4}{*}{14.005} & \multirow{4}{*}{.000} \\
\hline & 2nd & 3.3913 & 1.40580 & & \\
\hline & 3rd & 2.8065 & 1.40046 & & \\
\hline & 6th & 4.1250 & .67967 & & \\
\hline \multirow{4}{*}{$\begin{array}{l}\text { I feel afraid before the test in spite of } \\
\text { my good preparation }\end{array}$} & $1 \mathrm{st}$ & 4.5455 & .59580 & \multirow{4}{*}{10.864} & \multirow{4}{*}{.000} \\
\hline & 2nd & 3.5217 & 1.27456 & & \\
\hline & 3rd & 2.6774 & 1.53595 & & \\
\hline & 6th & 3.7917 & 1.02062 & & \\
\hline \multirow{4}{*}{ I take enough rest before the test. } & $1 \mathrm{st}$ & 4.4545 & .67098 & \multirow{4}{*}{3.360} & \multirow{4}{*}{.022} \\
\hline & 2nd & 4.1304 & 1.01374 & & \\
\hline & 3rd & 3.6774 & 1.27507 & & \\
\hline & 6th & 3.6250 & 1.05552 & & \\
\hline \multirow{4}{*}{$\begin{array}{l}\text { I encounter problems in answering } \\
\text { oral tests questions. }\end{array}$} & $1 \mathrm{st}$ & 4.4545 & .73855 & \multirow{4}{*}{6.128} & \multirow{4}{*}{.001} \\
\hline & 2nd & 2.9130 & 1.56417 & & \\
\hline & 3rd & 3.4839 & 1.26151 & & \\
\hline & 6th & 3.5417 & 1.14129 & & \\
\hline I prepare a programme to memorize & $1 \mathrm{st}$ & 4.4545 & .73855 & 1.656 & .182 \\
\hline
\end{tabular}




\begin{tabular}{|c|c|c|c|c|c|}
\hline Items & Level & Mean & $\begin{array}{c}\text { Std. } \\
\text { Deviation } \\
\end{array}$ & F test & $\begin{array}{c}\text { p- } \\
\text { value }\end{array}$ \\
\hline \multirow[t]{3}{*}{ the subject of the test. } & 2nd & 3.8696 & 1.01374 & & \\
\hline & 3rd & 3.9677 & 1.22431 & & \\
\hline & 6th & 3.9583 & .75060 & & \\
\hline \multirow{4}{*}{$\begin{array}{l}\text { I find difficulty in answering } \\
\text { subjective questions. }\end{array}$} & $1 \mathrm{st}$ & 4.3636 & .72673 & \multirow{4}{*}{24.238} & \multirow{4}{*}{.000} \\
\hline & 2nd & 2.3043 & 1.18455 & & \\
\hline & 3rd & 3.4839 & .99569 & & \\
\hline & 6th & 4.0833 & .40825 & & \\
\hline \multirow{4}{*}{$\begin{array}{l}\text { I find difficulty in going to sleep the } \\
\text { night before the test. }\end{array}$} & $1 \mathrm{st}$ & 4.2727 & .88273 & \multirow{4}{*}{.466} & \multirow{4}{*}{.707} \\
\hline & 2nd & 4.0435 & .76742 & & \\
\hline & 3rd & 4.0968 & .70023 & & \\
\hline & 6th & 4.0833 & .40825 & & \\
\hline \multirow{4}{*}{ I take hot drinks before the test. } & $1 \mathrm{st}$ & 4.4545 & .59580 & \multirow{4}{*}{38.658} & \multirow{4}{*}{.000} \\
\hline & 2nd & 2.3913 & 1.11759 & & \\
\hline & 3rd & 2.0323 & 1.19677 & & \\
\hline & 6th & 3.9583 & .62409 & & \\
\hline \multirow{4}{*}{$\begin{array}{l}\text { I always expect failure despite my } \\
\text { careful preparation. }\end{array}$} & $1 \mathrm{st}$ & 4.2727 & 1.03196 & \multirow{4}{*}{14.155} & \multirow{4}{*}{.000} \\
\hline & 2nd & 2.6957 & 1.14554 & & \\
\hline & 3rd & 2.6452 & 1.45025 & & \\
\hline & 6th & 4.0000 & .58977 & & \\
\hline \multirow{4}{*}{$\begin{array}{l}\text { I expect to get poor grades, even if I } \\
\text { try to answer well. }\end{array}$} & $1 \mathrm{st}$ & 3.9545 & .99892 & \multirow{4}{*}{11.212} & \multirow{4}{*}{.000} \\
\hline & 2nd & 2.4783 & 1.12288 & & \\
\hline & 3rd & 2.8065 & 1.30178 & & \\
\hline & 6th & 3.8333 & .70196 & & \\
\hline \multirow{4}{*}{$\begin{array}{l}\text { In the test, I answer the difficult } \\
\text { questions first and then the easy } \\
\text { ones }\end{array}$} & $1 \mathrm{st}$ & 4.0455 & .78542 & \multirow{4}{*}{1.708} & \multirow{4}{*}{.170} \\
\hline & 2nd & 3.4348 & 1.19947 & & \\
\hline & 3rd & 3.4516 & 1.52400 & & \\
\hline & 6th & 3.8333 & .56466 & & \\
\hline \multirow{4}{*}{$\begin{array}{l}\text { I spend much time in answering } \\
\text { each question. }\end{array}$} & $1 \mathrm{st}$ & 4.0455 & .84387 & \multirow{4}{*}{24.371} & \multirow{4}{*}{.000} \\
\hline & 2nd & 2.0435 & .87792 & & \\
\hline & 3rd & 2.5161 & 1.38735 & & \\
\hline & 6th & 3.9583 & .55003 & & \\
\hline \multirow{4}{*}{$\begin{array}{l}\text { I always feel that test instructions } \\
\text { are not clear. }\end{array}$} & $1 \mathrm{st}$ & 4.1364 & .77432 & \multirow{4}{*}{5.031} & \\
\hline & 2nd & 3.3043 & 1.29456 & & 003 \\
\hline & 3rd & 4.2581 & 1.03175 & & .003 \\
\hline & 6th & 3.7083 & .62409 & & \\
\hline & $1 \mathrm{st}$ & 4.3182 & .64633 & & \\
\hline $\begin{array}{l}\text { It is always difficult for me to } \\
\text { answer obiective }\end{array}$ & 2nd & 2.3043 & 1.25896 & & \\
\hline $\begin{array}{l}\text { answer oDjective questions, such as } \\
\text { MCOs* and true/false guestions }\end{array}$ & 3rd & 3.1613 & 1.12833 & 18.865 & .000 \\
\hline & 6th & 3.8750 & .61237 & & \\
\hline & $1 \mathrm{st}$ & 65.1818 & 9.00072 & & \\
\hline All its & 2nd & 47.0870 & 6.23708 & 30466 & (000 \\
\hline All tlems & 3rd & 49.1613 & 8.05025 & 50.400 & .000 \\
\hline & 6th & 58.5000 & 5.87552 & & \\
\hline
\end{tabular}

Critical value of $t$ at $\mathrm{df}$ "3, 99" and significance level 0.05 equal 2.68

Scheffe test is used to find direction of these differences according to multiple comparisons due to level. The differences for the benefit level $\left(1^{\text {nd }}\right.$ level $3^{\text {rd }}$ level), as follows: 
Scheffe test for Multiple Comparisons due to age

\begin{tabular}{|c|c|c|c|c|}
\hline Mean Difference & 1st & 2nd & 3rd & 6th \\
\hline 1st & 0 & $18.09486^{*}$ & $16.02053^{*}$ & $6.68182^{*}$ \\
\hline 2nd & $18.09486^{*}$ & 0 & -2.07433 & $-11.41304^{*}$ \\
\hline 3rd & $16.02053^{*}$ & -2.07433 & 0 & $-9.33871^{*}$ \\
\hline 6th & $6.68182^{*}$ & $-11.41304^{*}$ & $-9.33871^{*}$ & 0 \\
\hline
\end{tabular}

\section{Results and Recommendation Conclusion}

The results of the students' questionnaires reveal the following:

1-Students who become anxious while taking tests do not actually suffer from test anxiety, but the anxiety that comes from not being prepared.

2-Students blame test anxiety on poor grades, but it could be that they do not have the right study skills habits.

3-Students who have notes and have already learned the material, will not be stressful. Last minute studying only increases students' anxiety and inhibits their ability to remember things they learned a while ago.

4-One of the most recurrent problems students encounter when taking essay tests is that they frequently run out of time and can hence not complete all the questions.

5-The majority of the students arrive at the test place early.

6-There is no a significant difference in test anxiety according to the sex of the learner.

7-Students rarely use relaxation techniques to reduce their test anxiety.

8-Students may loose points or marks as a result of not reading the instructions well.

\section{Recommendations} following:

According to the results obtained, the researcher recommend the

1-Students should set reasonable goals for themselves when studying for tests. They can think of possible questions that could be on the test which are taken from their notes. An important aspect of studying is reviewing previous quizzes on the same subject material they are being tested on. Students who feel to perform well on a test may be willing to compromise their integrity with a plan to cheat. Of course, this kind of academic dishonesty has no place among college students. Not only that, such dishonesty can contribute to their anxiety.

2-Students can give themselves a certain amount of time for each question. They should leave extra time at the end of the test to finish their 
incomplete answers. Reviewing answers to check that there are no blank spots is a good idea.

3-Students should read the instructions over carefully and several times to avoid inaccuracy and/or falling for any "trick questions".

4-Students should answer the easy questions first and the more difficult questions later to avoid losing points in easy or simple questions.

5-In urgent cramming, students should look at what they need to review, skim and be selective, and concentrate on main points and ideas instead of menial details.

6-Several students have a lot of trouble in finishing essay tests because they tend to write too much. Students should concentrate more on covering all the major points of the essay and not so much on the details within each topic. If they run out of time when writing the essay, they should quickly write down in outline from what they would write if they had the time.

7- It is better to study material over a long period and repeat the process of studying repeatedly. This helps store the information in one's long term memory and reinforces it in one's mind.

8-Once a student arrives in the classroom and the test is on his desk, the first minutes of a test period are critical. First, he should listen carefully to any guidance that the instructor has to offer after distributing the test. The student should take several minutes to survey the entire test and read all the directions carefully. The amount of time he spends on any type of question will vary according to his own preferences and strengths. By planning, for instance, twenty minutes of his time for multiple-choice questions and saving fifty minutes for working on the essay

\section{References:}

Beck, J. (2007). Wadsworth Quick Guide to Test Anxiety. U.S.A.: The P.A. Hutchison Company.

Bickfords, A. (2000). "Strategies for Test Questions". Dr. Jacobs Articles. E/f period.

Bourne, E. (2000). The Anxiety and Phobia Workbook. Oakland: New Harbinger Publications.

Brodsky, M. (2004). Preparing for Tests. Retrieved October, 2004 from www.mth.msu.edu/mccarthy/student.information/testprep.html

Brown, J. (1995). No More Monsters in the Closet: Teaching Your Children to Overcome Everyday Fears and Phobias. New York: New York NY Prince.

Budd, B. (2002). Reducing Exam Anxiety and Improving Concentration. Retrieved September, 2002 from http:// www. Yorku. $\mathrm{Ca}$ /cdc//Sp/ep/exam6.htm 
Burns, D. (2004). "Anxiety at the Time of the Final Exam: Relationship with Expectations and Performance". Journal of Education for Business, 80 (2), 119-124.

Casbarro, J. (2005). Test Anxiety \& What You Can Do About It. A Practical Guide for Teachers, Parents, and Kids. U.S.A: National Professional Resources, Inc

Casey, S. (2002). Coping with Exams and Exam Anxiety. Retrieved January, 2002 from http:// www. Dartmouth.edu/admin/acskills/ISg/exams.html

Chargar, E. (2002). Test Anxiety. Retrieved January, 2002 from http:// www.umr.edu/ cousel/test.

Cole, A. (2003). Test Taking and Test Anxiety. Retrieved October, 2003 from http://www.utdallas.edu// student/slife/counseling/testanx.html

Coon, D. (1986). Introduction to Psychology: Exploration and Application. West Publishing.

Dacey, J. \& et al. (2000). Your Anxious Child: How Parents and Teachers Can Relieve Anxiety in Children. New York: Jossey-Bass.

Davidson, P. \& et al. (2005). Assessment in The Arab World. United Arab Emirates: Midex Advertising \& Publishing:

Fieber, S. (2001). Test anxiety. Retrieved January, 2002 form http:// www. Counseling. Uci. Edu/counsel/testanx.html

Germin, K. (2000). Test anxiety. Retrieved October, 2000 from http:// www.shsu.edu/ counsel/test.

Gershaw, D. A. (1988). Dealing with Test Anxiety. Retrieved August, 2005 from $/ / \mathrm{H}: / c d / 120 \%$ Anxiety. htm.

Horwitz, E. M. and Cope, J. (1986). “Foreign language Classroom Anxiety”. The Modern Language Journal 70(ii): 125-13

Krivoshik, L. (2003). Taking Essays Tests. Retrieved April, 2003 from http://www.uncc.edu/univlern/webmodules/esaytst 2b.html

Lash, J. (2004). Arousal and Anxiety. Psychological Service Centre: University of Cincinnati.

Liu, C. (2004). Test Anxiety: Overcoming test Anxiety. Retrieved March, 2004 from http:// www.uic.edu/depts/counseletr/ace/testanxiety.htm

Ludemann, K. (2004). Reducing Test Anxiety to Increase Testing Performance Anxiety. Retrieved July 2005 from http://www.psc.ue.edu.

Lyness, D. (2004). What is Test Anxiety. Retrieved February, 2004 from file://H:/cd/test\%20 Anxiety.htm

Mann, W. (2004). Test and Performance Anxiety. Retrieved August, 2004 from http://www.psc.uc.edu

Militana, E. (2003). Coping with Test Anxiety. Retrieved February, 2003 from http://www.iss.stthomas.edu/studyguides/tstprp8.htm

Milnamow, K. (2001). Relieving Test Anxiety. Retrieved October 2001 from http://www.mxctc.commnet.edu/clc/testanxy.htm 
Nolting, P.D. (2000). Your Guide to Reducing Test Anxiety and Improving Study Strategies. Houghton Mifflin Company.

Petrowski, S. (2002). Reducing Test Anxiety. Retrieved February, 2002 from http://www.byu.edu/stlife/edc/Learning Strategies/test/anxiety.htm

Shaw, M. (1995). Your Anxious Child: Raising a Healthy Child in a Frightening World. New York: Birch Lane Press.

Sullivan, A. (2003). Preparing for Exams. Retrieved October, 2003 from http://caps.une.edu/examprep.htm

Turner, E. (2003). Study Skills: How to Keep Calm During Tests. Retrieved from http://www.utexas.edu/student/utlc/handouts/1305.html

Van, S. (2003). "Preparing for Tests". Harvard-Westlake School. Vol.3/25.

Young, C. (2003). Preparing for Tests. Retrieved August, 2003 from http: www.sunynassau.edu/dptpages/ashs/lab/Study.html 